\title{
Formation of a Biotin Precursor, Pimelic Acid, in Yeasts from $\mathrm{C}_{18}$ Fatty Acids
}

\author{
Masahiro OHSUGI, Kayoko MIYAUCHI, Kayoko TACHIBANA, \\ and Shoko NAKAO ${ }^{1}$ \\ Laboratory of Food Microbiology, Department of Food Science, \\ Faculty of Home Economics, Mukogawa Women's University, \\ Nishinomiya 663, Japan \\ (Received May 10, 1988)
}

\begin{abstract}
Summary The biosynthesis of biotin-vitamers from $\mathrm{C}_{18}$ fatty acids in the resting cell reaction system of yeasts was investigated. The formation of pimelic acid (a biotin precursor) and biotin-vitamers (a mixture of 7keto-8-aminopelargonic acid and dethiobiotin) from linolenic, linoleic, and oleic acids was observed in certain yeasts belonging to the genera Cryptococcus, Candida, Rhodotorula, and Trichosporon. Metabolites from linolenic acid were analyzed by gas-liquid chromatography and mass spectrometry. Linoleic, oleic, stearic, heptadecanoic, palmitic, pentadecanoic, and pimelic acids were identified as metabolites of linolenic acid. The existence of a route to pimelic acid from linolenic acid in a strain of Rhodotorula rubra AKU 4836 was also indicated.
\end{abstract}

Key Words $\mathrm{C}_{18}$ fatty acids and biotin, biotin biosynthesis in yeasts

Since Mueller et al. demonstrated that oleic acid $\left(\mathrm{C}_{18=1}\right)$ was able to replace biotin in a biotin-requiring microorganism $(l)$, several subsequent investigations have failed to clarify the details of the participation of $\mathrm{C}_{18=1}$.

Based on our investigation using a strain of Bacillus sphaericus AKU 0277, we previously reported the participation of linolenic acid $\left(\mathrm{C}_{18=3}\right)$, linoleic acid $\left(\mathrm{C}_{18=2}\right)$, and $\mathrm{C}_{18=1}$ in the formation of biotin-vitamers and proposed the existence of a route to pimelic acid, which is an important precursor of biotin(2). In this organism, $\mathrm{C}_{18=3}, \mathrm{C}_{18=2}$, and $\mathrm{C}_{18=1}$ hydrogenated to form stearic acid $\left(\mathrm{C}_{18}\right)$; $\mathrm{C}_{18}$ and its $\beta$-oxidation product palmitic acid $\left(\mathrm{C}_{16}\right)$ decarboxylated to form heptadecanoic acid $\left(\mathrm{C}_{17}\right)$ and pentadecanoic acid $\left(\mathrm{C}_{15}\right)$, respectively. We investigated the occurrence of biotin biosynthesis from certain fatty acids in some

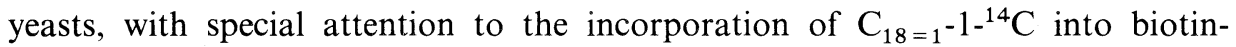
vitamers (3), the cultivation conditions for biotin-vitamer formation from $\mathrm{C}_{18=1}$ (4), and the formation of pimelic acid from azelaic acid(5). Nothing is known

\footnotetext{
1 大杉匡弘，宮内加代子，立花加代子，中尾祥子
} 
concerning the participation of $\mathrm{C}_{18}$ fatty acids $\left(\mathrm{C}_{18=3}, \mathrm{C}_{18=2}, \mathrm{C}_{18=1}\right.$, and $\left.\mathrm{C}_{18}\right)$ on biotin biosynthesis in yeasts. This paper will discuss the formation of biotinvitamers from $\mathrm{C}_{18}$ fatty acids in Rhodotorula rubra AKU 4836.

\section{EXPERIMENTAL}

Strains and medium. Six strains of yeasts which produce pimelic acid from azelaic acid (as described previously (5)) were used in this study. These organisms were grown in a medium consisting of $1 \%$ glucose, $0.5 \%$ peptone, $0.3 \%$ malt extract, and $0.3 \%$ yeast extract in tap water. The initial $\mathrm{pH}$ of the medium was adjusted to 6.0 .

Preparation and reaction system of resting cells. Each organism was grown at $28^{\circ} \mathrm{C}$ for $38 \mathrm{~h}$ while being constantly shaken in a $500 \mathrm{ml}$ flask containing $100 \mathrm{ml}$ of medium. The harvested cells were washed three times with saline solution and finally suspended in $1 / 200 \mathrm{M}$ potassium phosphate buffer $(\mathrm{pH} 7.0)$. The cell suspension (20-40 mg/ml each) was incubated with or without $\mathrm{C}_{18=3}, \mathrm{C}_{18=2}, \mathrm{C}_{18=1}$, or $\mathrm{C}_{18}(4 \mathrm{mg} / \mathrm{ml})$ in $2 \mathrm{ml}$ of $0.2 \mathrm{M}$ Tris- $\mathrm{HCl}$ buffer $(\mathrm{pH} 7.5)$ at $28^{\circ} \mathrm{C}$ and constantly shaken. After a $24-$ or 48-h incubation, the cells were removed by centrifugation. The supernatant was used as a sample for identification of metabolites from $\mathrm{C}_{18=3}$, $\mathrm{C}_{18=2}$, or $\mathrm{C}_{18=1}$.

Determination of pimelic acid and biotin-vitamers. Pimelic acid and biotinvitamers in the supernatant were assayed with Bacillus sphaericus(6), and Saccharomyces cerevisiae (7), respectively. Separation of metabolites derived from $\mathrm{C}_{18=3}, \mathrm{C}_{18=2}$, and $\mathrm{C}_{18=1}$ was accomplished by gas-liquid chromatography. The supernatant was acidified with $4 \mathrm{~N} \mathrm{HCl}$ and the metabolites were extracted three times with $4 \mathrm{ml}$ each of ethylether. The extract was concentrated, dehydrated with anhydrous $\mathrm{Na}_{2} \mathrm{SO}_{4}$, methylated with $\mathrm{BF}_{3}$-methanol reagent $(8)$, and analyzed by gas-liquid chromatography using the same procedure as described previously (2).

Determination of acetic acid. Reaction mixture contained $\mathrm{C}_{18}-\mathrm{C}_{10}$ fatty acid

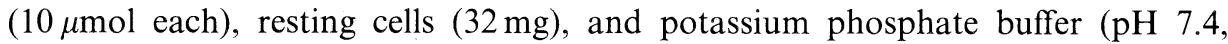
$67 \mathrm{~mm}$ ) in a total volume of $1.5 \mathrm{ml}$. For the control, fatty acid was replaced with water. Incubation was carried out for $90 \mathrm{~min}$ at $28^{\circ} \mathrm{C}$ while being constantly shaken. After incubation, the cells were removed by centrifugation. The resulting supernatant was assayed for acetic acid with acetokinase (9). The amount of acetohydroxamate formed was determined by the method of Lipmann and Tuttle(10), using Hiranuma EPO-3 type photometer at $530 \mathrm{~nm}$.

Decarboxylation of $\left[1-{ }^{14} C\right]$ fatty acid by resting cells. Warburg vessel $(2 \mathrm{ml})$ contained $\left[1-{ }^{14} \mathrm{C}\right]$ fatty acid $(0.17 \mu \mathrm{mol}, 0.2 \mu \mathrm{Ci})$, resting cells $(2.5 \mathrm{mg}$ dry weight $)$, $0.02 \mathrm{M}(\mathrm{pH} 7.0)$ potassium phosphate buffer, mixed with unlabeled fatty acid $(5 \mu \mathrm{mol})$. After a 30 -min incubation at $37^{\circ} \mathrm{C}$, an aliquot of $10 \mu \mathrm{l}$ drawn from $0.2 \mathrm{ml}$ of $15 \% \mathrm{KOH}$ in the center well was transferred to vials containing a scintillation mixture of the same composition as that described by Goldmark and Linn (11). Radioactivity was determined using an automatic liquid scintillation analyzer 
(Beckman, LS-3155P Liquid Scintillation System).

Mass spectrometry. A Hitachi Model RMU-6M mass spectrometer was used to identify the components fractionated by the gas chromatogram. The operating parameters were as follows: interface temperature, $200^{\circ} \mathrm{C}$; injection temperature, $200^{\circ} \mathrm{C}$; ion acceleration voltage, $3.2 \mathrm{kV}$; chamber voltage, $20 \mathrm{eV}$.

Materials. Acetokinase (1,530 units/mg, lyophilized) from Bacillus stearothermophilus was purchased from Unitika Co., Ltd., Japan. $\left[1-{ }^{14} \mathrm{C}\right]$ Fatty acids were obtained from Amersham Radiochemical Centre, England.

\section{RESULTS}

\section{Formation of biotin-vitamers from $C_{18}$ fatty acids}

In a previous paper (5), we demonstrated that pimelic acid was formed in the resting cell reaction system of certain yeasts from azelaic acid. Here, the formation of biotin-vitamers in $R$. rubra AKU 4836 from $\mathrm{C}_{18}$ fatty acids was examined. Figure 1 shows the time course formation of biotin-vitamers from pimelic acid, azelaic acid, $\mathrm{C}_{18=3}, \mathrm{C}_{18=2}$, and $\mathrm{C}_{18=1}$. Biotin-vitamers, namely, mixtures of dethiobiotin and 7-keto-8-aminopelargonic acid were identified through paper chromatography and assay with $S$. cerevisiae. The amount of biotin-vitamers formed from pimelic and azelaic acids increased as a function of incubation time. The formation of biotin-vitamers from $\mathrm{C}_{18=3}, \mathrm{C}_{18=2}$, and $\mathrm{C}_{18=1}$ was found to begin after about 20 , 15 , and $10 \mathrm{~h}$ of incubation, respectively. No biotin-vitamers were leaked from resting cells.

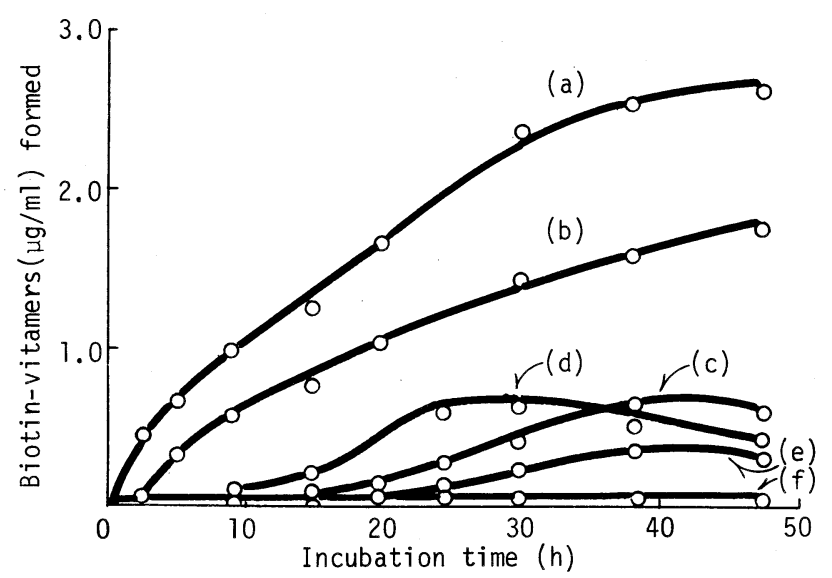

Fig. 1. Time course of formation of biotin-vitamers from several fatty acids in resting cell reaction system of Rhodotorula rubra AKU 4836. Reaction mixture composition and reaction conditions were the same as those described in EXPERIMENTAL except that pimelic acid (a), azelaic acid (b), $\mathrm{C}_{18=2}$ (c), $\mathrm{C}_{18=1}(\mathrm{~d})$, and $\mathrm{C}_{18=3}$ (e) was added to the reaction mixture. For the control, abbreviated as (f) in the figure, fatty acid was replaced with water. 


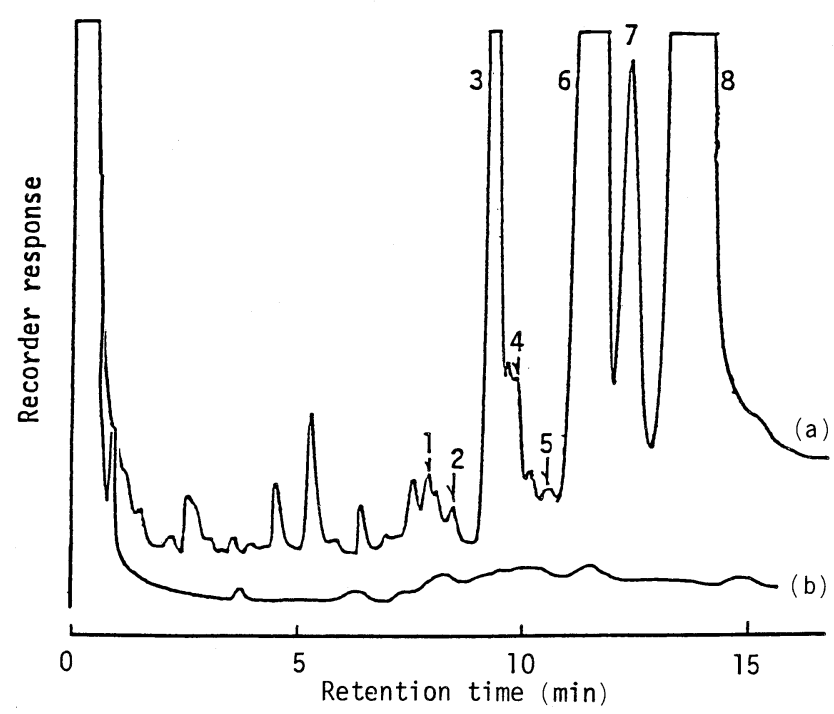

Fig. 2. Gas-liquid chromatogram of reaction products derived from $\mathrm{C}_{18=3}$ in resting cell reaction system of Rhodotorula rubra AKU 4836. The reaction mixture composition and reaction conditions were the same as in EXPERIMENTAL. (a), incubation with addition of $\mathrm{C}_{18=3}$; (b), incubation without addition of $\mathrm{C}_{18=3}$.

Table 1. Summary of metabolites derived from $\mathrm{C}_{18=3}, \mathrm{C}_{18=2}$, or $\mathrm{C}_{18=1}$ in resting cell reaction system of certain yeasts.

The reaction mixture composition and reaction conditions were the same as in EXPERIMENTAL. Each fatty acid derived from $\mathrm{C}_{18=3}, \mathrm{C}_{18=2}$, or $\mathrm{C}_{18=1}$ was determined and identified by gas-liquid chromatography and mass spectrometry. The hyphen $(-)$ in the table indicates negligible or undetectable amount of fatty acid. The abbreviation $\left(\mathrm{DC}_{7}\right)$ in the table means pimelic acid.

\begin{tabular}{|c|c|c|c|c|c|c|c|c|c|}
\hline \multirow{2}{*}{ Microbes } & \multirow{2}{*}{ Substrate } & \multicolumn{8}{|c|}{ Relative percent $(\%)$ of fatty acid found } \\
\hline & & $\mathrm{C}_{18=3}$ & $\mathrm{C}_{18=2}$ & $\mathrm{C}_{18=1}$ & $\mathrm{C}_{18}$ & $\mathrm{C}_{17}$ & $\mathrm{C}_{16}$ & $\mathrm{C}_{15}$ & $\mathrm{DC}_{7}$ \\
\hline \multirow{2}{*}{$\begin{array}{l}\text { Cryptococcus } \\
\quad \text { neoformans AKU } 4501\end{array}$} & $\mathrm{C}_{18=3}$ & 52.3 & 15.4 & 14.3 & - & - & 4.8 & - & 0.9 \\
\hline & $\mathrm{C}_{18=2}$ & - & 51.3 & 18.3 & 3.4 & 2.8 & 9.5 & 1.4 & - \\
\hline \multirow{2}{*}{$\begin{array}{l}\text { Rhodotorula } \\
\quad \text { rubra AKU } 4817\end{array}$} & $\mathrm{C}_{18=3}$ & 51.3 & 9.2 & 16.8 & 2.0 & 3.6 & 6.8 & - & 1.3 \\
\hline & $\mathrm{C}_{18=2}$ & - & 57.6 & 19.5 & - & 4.1 & 4.1 & 0.9 & 1.0 \\
\hline $\begin{array}{l}\text { Rhodotorula } \\
\quad \text { rubra AKU } 4836\end{array}$ & $\mathrm{C}_{18=3}$ & 31.6 & 11.9 & 27.6 & 1.4 & 1.1 & 10.6 & 0.5 & 1.1 \\
\hline \multirow{2}{*}{$\begin{array}{l}\text { Trichosporon } \\
\quad \text { cutaneum AKU } 4864\end{array}$} & $\mathrm{C}_{18=2}$ & - & 65.8 & 2.5 & - & 4.2 & 6.4 & 10.1 & - \\
\hline & $\mathrm{C}_{18=1}$ & - & - & 54.8 & 2.3 & 5.9 & 5.2 & 13.5 & - \\
\hline
\end{tabular}


Identification of metabolites derived from $C_{18}$ fatty acids

As described above, the bioassay showed that the organism formed biotinvitamers from each of the $\mathrm{C}_{18=3}, \mathrm{C}_{18=2}$, and $\mathrm{C}_{18=1}$ in the resting cell reaction system. Metabolites derived from $\mathrm{C}_{18=3}$ in the resting cell reaction system of the organism were fractionated by gas chromatography. Figure 2 shows the gas chromatogram of several fatty acids derived as metabolites from $\mathrm{C}_{18=3}$ (peak 8 ) in a strain of $R$. rubra AKU 4836. Figure 3 shows the mass spectra of these fatty acids. Peaks 1, 3, 4, 6, and 7 were identified as pimelic acid, palmitic acid $\left(\mathrm{C}_{16}\right)$, heptadecanoic acid $\left(\mathrm{C}_{17}\right), \mathrm{C}_{18=1}$, and $\mathrm{C}_{18=2}$, respectively. Peaks 2 and 5 (mass spectra not shown in Fig. 3) showed $m / z$ of $\left\{74,87,143,213(\mathrm{M}-43)^{+}\right.$, $\left.225(\mathrm{M}-31)^{+}, 256(\mathrm{M})^{+}\right\}$and $\left\{74,87,143,255(\mathrm{M}-43)^{+}, 267(\mathrm{M}-31)^{+}, 298(\mathrm{M})^{+}\right\}$,

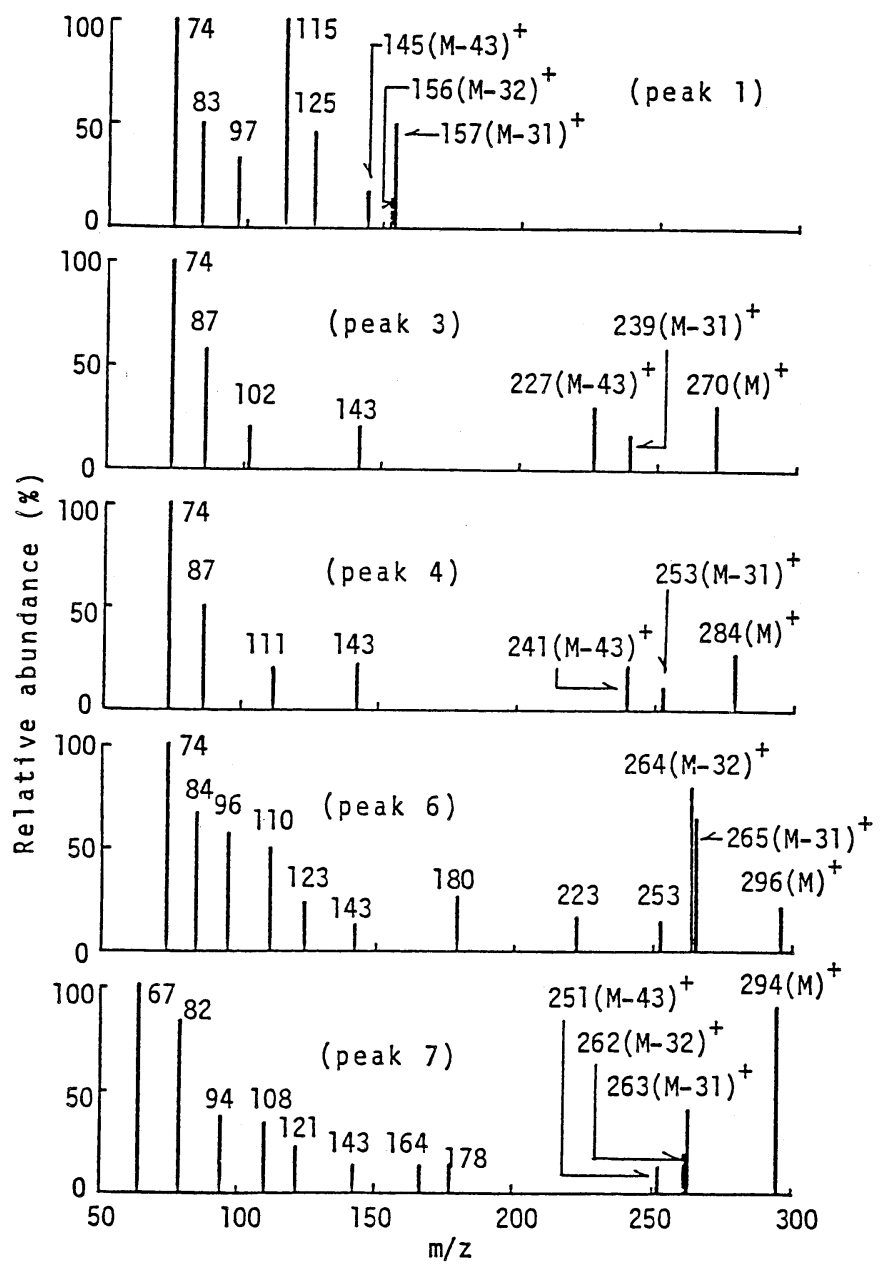

Fig. 3. Mass spectra of peaks $1,3,4,6$, and 7. 
and were identified as pentadecanoic acid $\left(\mathrm{C}_{15}\right)$ and $\mathrm{C}_{18}$, respectively. The other components separated remained unidentified. Table 1 shows the metabolites derived from $\mathrm{C}_{18=3}, \mathrm{C}_{18=2}$, and $\mathrm{C}_{18=1}$ in $R$. rubra AKU 4836 and three other yeast strains. The metabolic components derived from $\mathrm{C}_{18=3}$ in a strain of $R$. rubra AKU 4836 were almost identical with those derived from $\mathrm{C}_{18=3}$ in both strains of Cryptococcus neoformans AKU 4501 and $R$. rubra AKU 4817. The metabolites derived from $\mathrm{C}_{18=2}$ and $\mathrm{C}_{18=1}$ were similar to those derived from $\mathrm{C}_{18=3}$.

Formation of a biotin precursor, pimelic acid, from $C_{18}$ fatty acids in the resting cell reaction system of $R$. rubra $A K U 4836$

1) Decarboxylation ( $\alpha$-oxidation). As shown in Figs. 2 and 3 and in Table 1, $\mathrm{C}_{15}$ and $\mathrm{C}_{17}$ were identified as metabolites derived from $\mathrm{C}_{18=3}$ in the strains tested. The oxidation of several fatty acids was examined, using a radioactively labeled free acid as substrate, in accordance with the conventional Warburg manometric technique. Table 2 shows the results of the measurements of ${ }^{14} \mathrm{CO}_{2}$ produced from $\left[1-{ }^{14} \mathrm{C}\right]$ fatty acids during incubation with the resting cells. $\mathrm{C}_{18}$ and $\mathrm{C}_{16}$ were effective substrates, but shorter saturated fatty acids such as myristic acid $\left(\mathrm{C}_{14}\right)$, lauric acid $\left(\mathrm{C}_{12}\right)$, and octanoic acid $\left(\mathrm{C}_{8}\right)$, as well as $\mathrm{C}_{18}$ unsaturated fatty acids $\left(\mathrm{C}_{18=3}, \mathrm{C}_{18=2}\right.$, and $\mathrm{C}_{18=1}$ ) were ineffective. Metabolites derived from $\mathrm{C}_{18}$ and $\mathrm{C}_{16}$ by the organism were also investigated using GC-MS analysis. Decarboxylation of $\mathrm{C}_{18}$ and $\mathrm{C}_{16}$ occurred and caused the formation of odd-chain fatty acids of $\mathrm{C}_{17}$ and $\mathrm{C}_{15}$ (Table 3). Table 3 also shows the formation of odd-chain fatty acids from $C_{18}$ and $C_{16}$ in the other five strains, including the formation of $\mathrm{C}_{16}$ from $\mathrm{C}_{18}$.

2) $\beta$-Oxidation. In addition to $\mathrm{C}_{17}$ and $\mathrm{C}_{15}, \mathrm{C}_{16}$ was identified as an oxidation product of $\mathrm{C}_{18}$ in the strains tested (Table 3 ). Figure 4 shows the formation of acetic acid, the major product of the $\beta$-oxidation of fatty acids, from various fatty acids in

Table 2. ${ }^{14} \mathrm{CO}_{2}$ production from $\left[1-{ }^{14} \mathrm{C}\right]$ fatty acids in resting cell reaction system of Rhodotorula rubra AKU 4836.

The reaction mixture composition and reaction conditions are described in EXPERIMENTAL. As the control, each fatty acid and boiled resting cells were allowed to react.

\begin{tabular}{ccc}
\hline & \multicolumn{2}{c}{${ }^{14} \mathrm{CO}_{2}$ produced $(\%$ of counts added $)$} \\
\cline { 2 - 3 } & Boiled & Unboiled \\
\hline $\mathrm{C}_{18=3}$ & 0 & 0 \\
$\mathrm{C}_{18=2}$ & 0.1 & 0.1 \\
$\mathrm{C}_{18=1}$ & 0 & 0 \\
$\mathrm{C}_{18}$ & 0.9 & 34.3 \\
$\mathrm{C}_{16}$ & 1.1 & 13.7 \\
$\mathrm{C}_{14}$ & 0.2 & 0.3 \\
$\mathrm{C}_{12}$ & 0.1 & 0.9 \\
$\mathrm{C}_{8}$ & 1.1 & 1.2 \\
\hline
\end{tabular}


Table 3. Formation of odd-chain fatty acids from $\mathrm{C}_{18}$ and $\mathrm{C}_{16}$ in resting cell reaction system of certain yeasts.

The reaction mixture composition and reaction conditions were the same as in EXPERIMENTAL. Each fatty acid derived from $\mathrm{C}_{18}$ and $\mathrm{C}_{16}$ was determined and identified by gas-liquid chromatography and mass spectrometry. The hyphen $(-)$ in the table indicates negligible or undetectable amount of fatty acid.

\begin{tabular}{|c|c|c|c|c|}
\hline \multirow{2}{*}{ Microbes } & \multirow{2}{*}{ Substrate } & \multicolumn{3}{|c|}{ Relative percent $(\%)$ of } \\
\hline & & $\mathrm{C}_{17}$ & $\mathrm{C}_{16}$ & $\mathrm{C}_{15}$ \\
\hline $\begin{array}{l}\text { Cryptococcus } \\
\quad \text { neoformans AKU } 4501\end{array}$ & $\begin{array}{l}\mathrm{C}_{18} \\
\mathrm{C}_{16}\end{array}$ & $\frac{4.3}{-}$ & 5.7 & $\begin{array}{l}4.6 \\
5.1\end{array}$ \\
\hline $\begin{array}{l}\text { Candida } \\
\quad \text { lipolytica } \text { AKU } 4582\end{array}$ & $\begin{array}{l}\mathrm{C}_{18} \\
\mathrm{C}_{16}\end{array}$ & $\frac{1.5}{-}$ & $\begin{array}{l}2.9 \\
-\end{array}$ & $\begin{array}{l}1.4 \\
2.9\end{array}$ \\
\hline $\begin{array}{l}\text { Rhodotorula } \\
\quad \text { rubra AKU } 4817\end{array}$ & $\begin{array}{l}\mathrm{C}_{18} \\
\mathrm{C}_{16}\end{array}$ & 5.1 & $\frac{6.3}{-}$ & $\begin{array}{l}5.1 \\
9.2\end{array}$ \\
\hline $\begin{array}{l}\text { Rhodotorula } \\
\text { rubra AKU } 4836\end{array}$ & $\begin{array}{l}\mathrm{C}_{18} \\
\mathrm{C}_{16}\end{array}$ & $\begin{array}{l}5.2 \\
-\end{array}$ & $\frac{3.7}{-}$ & $\begin{array}{l}6.4 \\
1.9\end{array}$ \\
\hline $\begin{array}{l}\text { Rhodotorula } \\
\text { sp. AKU } 4853\end{array}$ & $\begin{array}{l}\mathrm{C}_{18} \\
\mathrm{C}_{16}\end{array}$ & $\frac{9.4}{-}$ & $\begin{array}{c}11.9 \\
-\end{array}$ & $\begin{array}{r}17.4 \\
8.6\end{array}$ \\
\hline $\begin{array}{l}\text { Trichosporon } \\
\text { cutaneum AKU } 4864\end{array}$ & $\begin{array}{l}\mathrm{C}_{18} \\
\mathrm{C}_{16}\end{array}$ & $\begin{array}{l}4.3 \\
-\end{array}$ & $\begin{array}{c}12.1 \\
-\end{array}$ & $\begin{array}{l}8.8 \\
7.8\end{array}$ \\
\hline
\end{tabular}

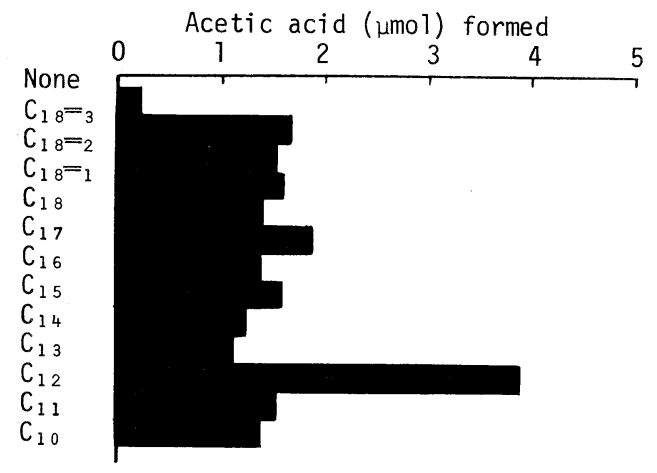

Fig. 4. Formation of acetic acid from several fatty acids in resting cell reaction system of Rhodotorula rubra AKU 4836. The reaction mixture composition and reaction conditions were the same as in EXPERIMENTAL. None, without addition of fatty acid; $\mathrm{C}_{11}$, hendecanoic acid.

the course of the resting cells reaction. The formation of acetic acid from $\mathrm{C}_{12}$ was most pronounced. Acetic acid formation was detectable in both odd- and evenchain fatty acids tested. Also unsaturated fatty acids such as $\mathrm{C}_{18=3}, \mathrm{C}_{18=2}$, and 


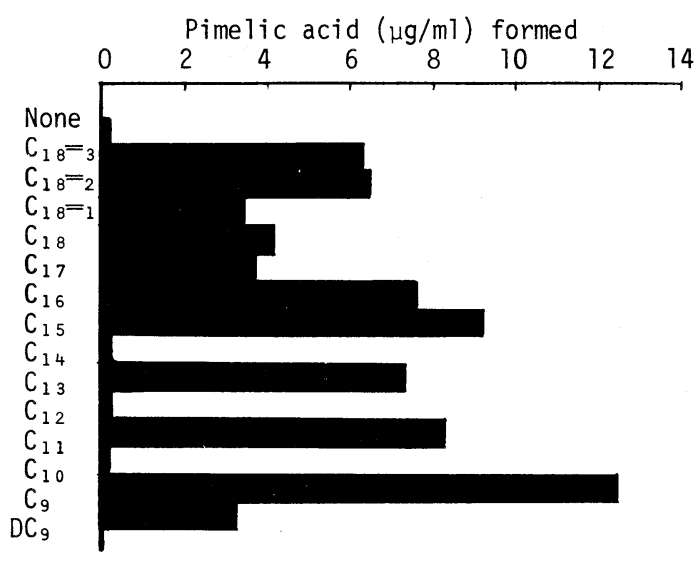

Fig. 5. Formation of pimelic acid from various fatty acids in resting cell reaction system of Rhodotorula rubra AKU 4836. The reaction mixture composition and reaction conditions were the same as in EXPERIMENTAL. None, incubation without addition of fatty acid; $\mathrm{DC}_{9}$, azelaic acid.

$\mathrm{C}_{18=1}$ served as substrates for the formation of acetic acid.

3) Pimelic acid formation. In the previous paper (5), we reported the formation of pimelic acid as a degradation product of azelaic acid in the six strains used in this study. Figure 5 shows the formation of pimelic acid from $\mathrm{C}_{9}-\mathrm{C}_{18}$ fatty acids by the organism in the resting cell reaction system. However, no formation of pimelic acid from $\mathrm{C}_{14}, \mathrm{C}_{12}$ or decanoic acid $\left(\mathrm{C}_{10}\right)$ was observed.

\section{DISCUSSION}

It is well known that pimelic acid is an important precursor of biotin biosynthesis, and that dethiobiotin is normally formed in the intermediate stage of biotin biosynthesis. However, the details of the biosynthetic route to pimelic acid still remain obscure (we discussed the relationship between fatty acid metabolism and biotin biosynthesis in microorganisms previously $(2-5,12-18)$. In one paper (2), we proposed the existence of the following route from $\mathrm{C}_{18=3}$ to pimelic acid in a strain of $B$. sphaericus $\mathrm{AKU} 0227$ : 1) hydrogenation of $\mathrm{C}_{18=3}$ to form $\mathrm{C}_{18}$ via $\mathrm{C}_{18=2}$ and $\mathrm{C}_{18=1} ; 2$ ) decarboxylation of $\mathrm{C}_{18}$ and $\mathrm{C}_{16}$ to form $\mathrm{C}_{17}$ and $\mathrm{C}_{15}$, respectively; 3) repeated $\beta$-oxidation of $\mathrm{C}_{17}$ and $\mathrm{C}_{15}$ to form pelargonic acid $\left.\left(\mathrm{C}_{9}\right) ; 4\right) \omega$-oxidation of $\mathrm{C}_{9}$ to form azelaic acid; and finally, 5) $\beta$-oxidation of azelaic acid to form pimelic acid.

Here, we have described the biosynthesis of biotin-vitamers from the substrates of $\mathrm{C}_{18=3}, \mathrm{C}_{18=2}$, and $\mathrm{C}_{18=1}$ in the resting cells of yeasts belonging to the genera Cryptococcus, Candida, Rhodotorula, and Trichosporon. As reported previously (4), these strains formed biotin-vitamers (mainly dethiobiotin) from $\mathrm{C}_{18=1}$ during cultivation. The cultivation of $C$. neoformans $\mathrm{AKU} 4501$ showed that $\mathrm{C}_{18=1}-1-{ }^{14} \mathrm{C}$ is 


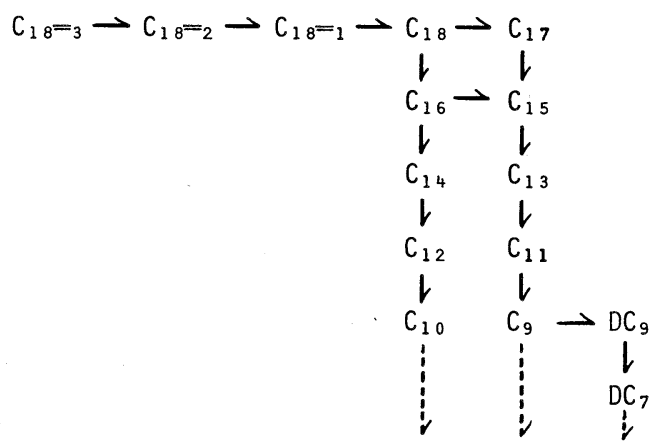

Fig. 6. Possible route from $\mathrm{C}_{18}$ unsaturated fatty acids to pimelic acid in biotin biosynthesis in Rhodotorula rubra AKU 4836. Dotted line in the figure means repeating $\beta$-oxidation. $\mathrm{DC}_{9}$, azelaic acid; $\mathrm{DC}_{7}$, pimelic acid.

incorporated into biotin-vitamers such as 7-keto-8-aminopelargonic acid, dethiobiotin, and biotin (3). In the present paper, we have shown that biotin-vitamers are formed from $\mathrm{C}_{18=3}, \mathrm{C}_{18=2}$, and $\mathrm{C}_{18=1}$ in the resting cell reaction system of these strains (Fig. 1). The metabolic intermediates derived from $\mathrm{C}_{18=3}$ in a strain of $R$. rubra AKU 4836 were similar to those intermediates found in strains of $C$. neoformans AKU 4501 and $R$. rubra AKU 4817 (Table 1). These findings suggest that the route of biosynthesis of biotin from $\mathrm{C}_{18=3}$ is identical in these yeast strains. The results of our manometric experiment and GC-MS analysis showed that $\mathrm{C}_{17}$ and $\mathrm{C}_{15}$ were formed from $\mathrm{C}_{18}$ and $\mathrm{C}_{16}$, respectively (Tables 2 and 3 ). These oddchain fatty acids degraded to form acetic acid by $\beta$-oxidation just as did the evenchain fatty acids (Fig. 4). We previously showed that, in Pseudomonas sp. strain 393, azelaic acid must be derived from $\mathrm{C}_{9}$ by $\omega$-oxidation(18). In our present investigation, several experiments on the decomposition of $\mathrm{C}_{9}$ were undertaken by incubating $\mathrm{C}_{9}$ together with resting cells of $R$. rubra AKU 4836 until azelaic acid was formed. Azelaic acid was identified by gas-liquid chromatography. During a 5$\mathrm{h}$ incubation (data not shown), both azelaic and pimelic acids were formed.

Based upon the above results, we propose the scheme shown in Fig. 6 for the route from $\mathrm{C}_{18}$ unsaturated fatty acids to pimelic acid in $R$. rubra AKU 4836. The biotin precursor (pimelic acid) can be seen to be formed from $\mathrm{C}_{18=3}$ as follows: 1) saturation (or hydrogenation) of $\mathrm{C}_{18=3}$ to form $\mathrm{C}_{18}$ via $\mathrm{C}_{18=2}$ and $\mathrm{C}_{18=1}$ as intermediates; 2) the conversion of $\mathrm{C}_{18}$ into the odd-chain fatty acid $\mathrm{C}_{17}$ by decarboxylation (or $\alpha$-oxidation); 3 ) the formation of $\mathrm{C}_{9}$ by repeated $\beta$-oxidation of $\mathrm{C}_{17}$; 4) $\omega$-oxidation of $\mathrm{C}_{9}$ to form the dicarboxylic acid azelaic acid; and 5) the formation of pimelic acid from azelaic acid by $\beta$-oxidation. Therefore, the metabolic route from $\mathrm{C}_{18}$ unsaturated fatty acids to pimelic acid is identical in both bacteria and yeasts. 


\section{REFERENCES}

1) Mueller, J. H., Cohen, S., and Synder, J. C. (1941): Factors concerned in the growth of Corynebacterium diphtheriae from minute inocula. J. Bacteriol., 41, 581-592.

2) Ohsugi, M., Miyauchi, K., and Inoue, Y. (1985): Biosynthesis of biotin-vitamers from unsaturated higher fatty acids by bacteria. J. Nutri. Sci. Vitaminol., 31, 253-263.

3) Ohsugi, M., and Ishikawa, Y. (1975): Biosynthesis of biotin-vitamers from oleic acid by Cryptococcus neoformans. Agric. Biol. Chem., 39, 559-560.

4) Inoue, Y., and Ohsugi, M. (1983): Effect of oleic acid on the formation of biotinvitamers by yeasts. Vitamins (J. Vitamin Soc. Jpn.), 57, 185-191.

5) Ohsugi, M., Miyauchi, K., and Inoue, Y. (1984): Pimelic acid as a degradation product of azelaic acid by yeasts. Agric. Biol. Chem., 48, 1881-1882.

6) Ohsugi, M., Miyauchi, K., and Inoue, Y. (1983): Pimelic acid determination with resting cell system of Bacillus sphaericus AKU 0218. Agric. Biol. Chem., 47, 1649-1650.

7) Snell, E. E., Eakin, R. E., and Williams, R. J. (1940): A quantitative test for biotin and observations regarding its occurrence and properties. J. Am. Chem. Soc., 62, 175-178.

8) Morrison, W. R., and Smith, L. M. (1964): Preparation of fatty acid methyl esters and dimethylacetals from lipids with boronfluoride-methanol. J. Lipid Res., 5, 600-608.

9) Rose, I. A. (1955): Acetate kinase of bacteria (acetokinase), in Methods in Enzymology, ed. by Colowick, S. P., and Kaplan, N. O., Academic Press, New York, Vol. 1, pp. 591-595.

10) Lipmann, F., and Tuttle, L. C. (1950): Lipase catalysed condensation of fatty acids with hydroxylamine. Biochim. Biophys. Acta, 4, 301-309.

11) Goldmark, P. L., and Linn, S. (1970): An endonuclease activity from Escherichia coli absent from certain rec ${ }^{-}$strains. Proc. Natl. Acad. Sci. U.S.A., 67, 434-441.

12) Ohsugi, M., Yang, H. C., and Ogata, K. (1972): Formation of desthiobiotin from oleic acid by Brevibacterium sp. Agric. Biol. Chem., 36, 1285-1291.

13) Ohsugi, M., and Baba, A. (1975): Biosynthesis of biotin-vitamers from pelargonic acid by Pseudomonas sp. Agric. Biol. Chem., 39, 731-732.

14) Ohsugi, M., and Inoue, Y. (1981): Formation of pimelic and azelaic acids, biotin intermediates, derived from oleic acid by Micrococcus sp. Agric. Biol. Chem., 45, $2355-2356$.

15) Inoue, Y., Iwatani, N., and Ohsugi, M. (1982): Effect of linoleic acid on the accumulation of biotin by a strain of Bacillus sp. Vitamins (J. Vitamin Soc. Jpn.), 56, 241-247.

16) Ohsugi, M., Inoue, Y., Ukisu, M., Imai, N., and Deguchi, H. (1982): Conversion of pelargonic acid to pimelic acid with Pseudomonas sp. cells. Agric. Biol. Chem., 46, 1391-1392.

17) Ohsugi, M., Inoue, Y., Iwatani, N., and Tsukamoto, M. (1983): Incorporation of [ $U$ ${ }^{14}$ C]linoleic acid into biotin by resting cells of Bacillus sp. Agric. Biol. Chem., 47, 1129-1131.

18) Ohsugi, M., Inoue, Y., Kuki, M., Imai, K., and Deguchi, H. (1983): Biosynthesis of biotin-vitamers from pelargonic acid by Pseudomonas sp. strain 393. Agric. Biol. Chem., 47, 2725-2730. 